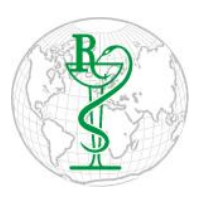

INDO GLOBAL JOURNAL OF

PHARMACEUTICAL SCIENCES

ISSN 2249- 1023

\title{
Method Development and Validation for Estimation of Casein in Milk
}

\author{
Himaja D., Manoj Kumar, Harun Rasheed Shaik, Manjunath S.Y., Sandip Sen * \\ Srikrupa Institute of Pharmaceutical Sciences, Velikatta, Siddipet, Telangana-502277, India
}

Address for Correspondence: Sandip Sen, sandipsen2010@gmail.com

\begin{abstract}
Received:
14.06.2019

Accepted:

27.12.2019

Published:

15.12.2020

Keywords

Casein; Milk;

UV-

spectrophotometr

ic method; ICH

guidelines;

Validation.
\end{abstract}

ABSTRACT: Milk contains $3.3 \%$ total protein and also contains 9 essential amino acids required by humans. Casein is one of the major categories of protein in milk. There are several spectrophotometric methods were carried out for the determination of total proteins in milk samples. Here we developed and validated a simple, accurate, specific and precise spectrophotometric method by using a UV spectrophotometer. In the proposed method $0.1 \mathrm{~N} \mathrm{NaOH}$ was used as a solvent. The $\lambda$ max of standard casein was found to be $219 \mathrm{~nm}$. It exhibited the linearity in the concentration range of $10-50 \mu \mathrm{g} / \mathrm{ml}$ with a correlation coefficient of 0.999 . The method was validated according to the ICH guidelines for the estimation of casein in milk. The validation studies of the method showed percentage Relative Standard Deviation (\% RSD) values less than $2 \%$ indicating that the developed method is precise. The percentage recovery of the casein for the proposed method was found to be $99 \%$. So the developed method can be used for the estimation of casein in the milk sample. (C) 2020 iGlobal Research and Publishing Foundation. All rights reserved.

Cite this article as: Himaja, D.; Kumar, M.; Shaik, H.R.; Manjunath, S.Y.; Sen, S. Method development and validation for estimation of casein in milk. Indo Global J. Pharm. Sci., 2020; 10(4): 27-31. DOI: http://doi.org/10.35652/IGJPS.2020.10405.

\section{INTRODUCTION}

The milk phosphoprotein, casein (pronounced KY-see) is present in the milk from all mammals. It is found in dairy products such as cheese, milk, and yogurt and is also used independently as an emulsifying and binding agent in countless processed foods, including "vegetarian" cheeses, "vegetarian" meats, cereals, bread, and supplements [1].

The total protein component of milk is composed of numerous specific proteins. The primary groups of milk proteins are the caseins. There are 3 or 4 caseins in the milk of most species; the different caseins are distinct molecules but are similar in structure. All other proteins found in milk are grouped together under the name of whey proteins. The major whey proteins in cow milk are $\beta$-lactoglobulin and $\alpha$-lactalbumin. The major milk proteins, including the caseins, $\beta$ lactoglobulin, and $\alpha$-lactalbumin, are synthesized in the mammary epithelial cells and are only produced by the mammary gland [2].

Many spectrophotometric methods have been evaluated for total protein determination in milk samples in the range of 220- $280 \mathrm{~nm}$ due to their tryptophan content, which shows an absorption maximum at this wavelength [3]. However, among them, the Bradford assay was used for the determination of total proteins in skim milk powder and whole milk powder instead of the Kjeldahl method [4]. Another spectrophotometric method was based on the alkaline solution-induced changing the spectrum of tyrosine to higher wavelength values in the UV region. In the range between 248 and $256 \mathrm{~nm}$, the absorbance was found to be a linear function of the wavelength and the slope coefficient is directly proportional to the protein concentration [5].

Based on the above study we have developed and validated cheap and accurate methods as per ICH guidelines. For the estimation of casein present in milk, $0.1 \mathrm{~N} \mathrm{NaOH}$ was used.

\section{MATERIALS AND METHODS}

All spectral measurements were carried out in ELICO SL 244 double beam UV-VIS spectrophotometer using $1.00 \mathrm{~cm}$ quartz cuvettes. The weighing process was carried out in SHIMADZU AUX 220.

\section{MILK SAMPLES AND SOLUTIONS}

A. Milk samples: The sample of milk purchased from the local market. 


\section{Indo Global Journal of Pharmaceutical Sciences, 2020; 10(4): 27-31}

B. Milk solutions: The milk sample was prepared in the following concentration of $0.125 \mathrm{~g} / \mathrm{l}$ for the UV-219nm

C. Extractor solution of chloroform and methanol: A solution of chloroform-methanol $(2: 1 \mathrm{v} / \mathrm{v})$ was prepared and used for the extraction of casein in milk samples.

\section{STANDARD SOLUTIONS}

Casein: Casein (Riedel) solutions were prepared in $\mathrm{NaOH}$ $0.10 \mathrm{M}$ and used as a standard in the following concentration, $0.125 \mathrm{~g} / \mathrm{l}$ for the UV-219.

\section{ASSAY METHODS FOR ESTIMATION OF CASEIN IN MILK}

\section{i. Extraction of casein}

A $5 \mathrm{ml}$ of sample milk, $18.0 \mathrm{ml}$ of the solution of chloroformmethanol were added. The tubes were sealed and shaken vigorously for $5 \mathrm{~min}$. The solutions were filtered using a quantitative filter paper and the organic phase was discarded. Then, $6.0 \mathrm{ml}$ of chloroform and $6.0 \mathrm{ml}$ of water were added to the solid samples and they were shaken for $5 \mathrm{~min}$ and filtered [3].

\section{ii. Selection of Analytical Wavelength}

$10 \mu \mathrm{g} / \mathrm{ml}$ solutions of casein were prepared in $0.1 \mathrm{M} \mathrm{NaOH}$ by appropriate dilution and the spectrum was recorded between 200-400 nm. The maximum wavelength of casein was found to be $219 \mathrm{~nm}$.

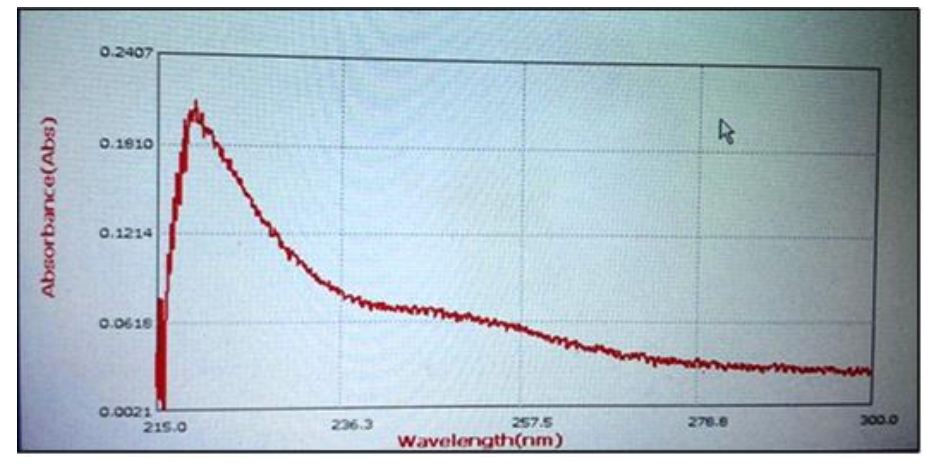

Fig 1: $\lambda$ max of casein at $219 \mathrm{~nm}$ by $U V$-spectroscopy

\section{METHOD VALIDATION}

The proposed method has been extensively validated in terms of specificity, linearity, accuracy, precision, robustness, ruggedness, limits of detection (LOD) and quantification (LOQ). The accuracy was expressed in terms of percent recovery of the known amount of the standard casein added to the known amount of the milk. The precision was expressed with respect to the repeatability, intra-day and inter-day variation in the expected casein concentrations. The method validation is carried out as per ICH guidelines [6].

\section{A. SPECIFICITY}

Specificity is the ability to assess the analyte in the presence of components which may be expected to be present. Typically these might include impurities, degradants, matrix, etc. Lack of specificity of an individual analytical procedure may be compensated by other supporting analytical procedure(s).

\section{B. LINEARITY}

The linearity of an analytical procedure is its ability (within a given range) to obtain test results which are directly proportional to the concentration (amount) of analyte in the sample.

\section{ACCURACY (\% RECOVERY)}

The accuracy of the method was determined by calculating the recovery of casein by the standard addition method. The accuracy of the analytical method was assessed by determination of recovery for three concentrations corresponding to 50,100 and $150 \%$ of test solution concentration. For each concentration, three sets were prepared. The mean recovery of casein was reported.

\section{PRECISION}

The degree of reproducible results produced by a sample at different conditions

D.1. Repeatability- Repeatability expresses the precision under the same operating conditions over a short interval of time.

D.2. Intermediate precision- Intermediate precision expresses within-laboratories variations: different days, different analysts, different equipment, etc.

D.3. Reproducibility- Reproducibility expresses the precision between laboratories (collaborative studies, usually applied to the standardization of methodology).

\section{E. ROBUSTNESS}

The robustness of an analytical procedure is a measure of its capacity to remain unaffected by small, but deliberate variations in method parameters and provides an indication of its reliability during normal usage. The robustness study was carried out by using $20(\mu \mathrm{g} / \mathrm{ml})$ concentration.

\section{F. RUGGEDNESS}

The ruggedness is to expresses within-laboratories variations: different days, different analysts, different equipment, etc. The ruggedness study was by using $20(\mu \mathrm{g} / \mathrm{ml})$ concentration.

\section{DETECTION LIMIT AND QUANTITATION LIMIT}

ICH guideline describes several approaches to determine the detection and quantitation limits. These include visual evaluation, signal-to-noise ratio and the use of standard 
Indo Global Journal of Pharmaceutical Sciences, 2020; 10(4): 27-31

deviation of the response and the slope of the calibration curve. In the present study, the LOD and LOQ were based on the third approach and were calculated according to the $3.3 \sigma / \mathrm{S}$ and $10 \sigma / \mathrm{S}$ criterions, respectively; where $\sigma$ is the standard deviation of $y$-intercepts of regression lines and $\mathrm{s}$ is the slope of the calibration curve.

\section{RESULTS AND DISCUSSION}

Table 1: Calibration curve of casein data

\begin{tabular}{|c|c|c|}
\hline S.NO & CONCENTRATION $(\boldsymbol{\mu g} / \mathbf{m l})$ & ABSORBANCE \\
\hline 1 & 10 & 0.5175 \\
\hline 2 & 20 & 0.6113 \\
\hline 3 & 30 & 0.7223 \\
\hline 4 & 40 & 0.8201 \\
\hline 5 & 50 & 0.9131 \\
\hline
\end{tabular}

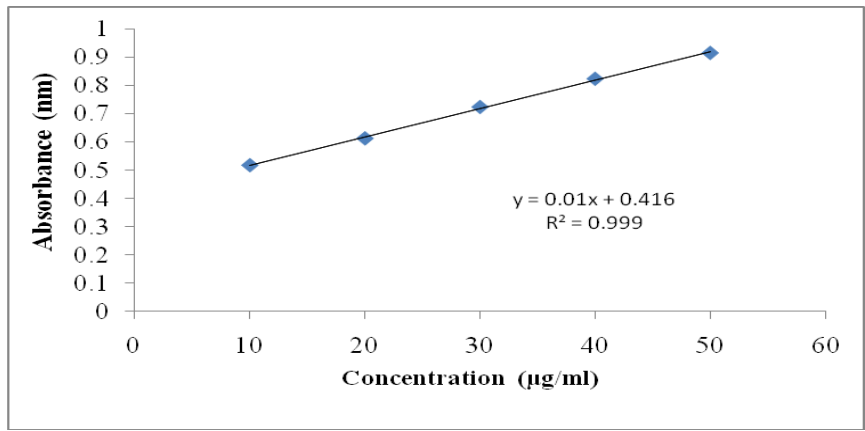

Fig 2: Calibration curve of casein
Table 2: Results of the assay of casein in milk.

\begin{tabular}{|c|c|c|c|c|c|}
\hline $\begin{array}{c}\text { S.N } \\
\mathbf{O}\end{array}$ & $\begin{array}{c}\text { CO } \\
\text { NC. } \\
(\boldsymbol{\mu g} / \\
\mathbf{m l})\end{array}$ & $\begin{array}{c}\text { STANDA } \\
\text { RD } \\
\text { ABSORB } \\
\text { ANCE }\end{array}$ & $\begin{array}{c}\text { TEST } \\
\text { ABSORB } \\
\text { ANCE }\end{array}$ & $\begin{array}{c}\text { AMO } \\
\text { UNT } \\
\text { FOUN } \\
\text { D }\end{array}$ & $\begin{array}{c}\text { \%PUR } \\
\text { ITY }\end{array}$ \\
\hline 1 & 20 & 0.6113 & 0.6103 & 19.344 & $96.7 \%$ \\
\hline 2 & 20 & 0.6113 & 0.6109 & 19.404 & $97 \%$ \\
\hline 3 & 20 & 0.6113 & 0.6104 & 19.354 & $96.7 \%$ \\
\hline 4 & 20 & 0.6113 & 0.6100 & 19.314 & $96.5 \%$ \\
\hline 5 & 20 & 0.6113 & 0.6099 & 19.304 & $96.5 \%$ \\
\hline
\end{tabular}

\begin{tabular}{|c|c|c|}
\hline $\begin{array}{c}\text { MEAN OF } \\
\text { ASSAY } \\
\text { VALUES }\end{array}$ & $\begin{array}{c}\text { STANDARD } \\
\text { DEVIATION }\end{array}$ & \% RSD \\
\hline 0.6103 & & \\
\hline
\end{tabular}

Table 3: Linearity

\begin{tabular}{|c|c|c|c|c|}
\hline $\begin{array}{c}\text { S.N } \\
\mathbf{O}\end{array}$ & $\begin{array}{c}\text { CONC. } \\
((\boldsymbol{\mu} \mathbf{g} / \mathbf{m l} \\
)\end{array}$ & $\begin{array}{c}\text { ABSORBANC } \\
\mathbf{E} \\
(\mathbf{m e a n}, \mathbf{N}=\mathbf{6})\end{array}$ & $\begin{array}{c}\text { STANDARD } \\
\text { DEVIATIO } \\
\mathbf{N}\end{array}$ & $\begin{array}{c}\text { \% RS } \\
\mathbf{D}\end{array}$ \\
\hline 1 & 10 & 0.5169 & 0.00051 & 0.0986 \\
\hline 2 & 20 & 0.6116 & 0.00040 & 0.0660 \\
\hline 3 & 30 & 0.7225 & 0.00047 & 0.0653 \\
\hline 4 & 40 & 0.8220 & 0.00132 & 0.1612 \\
\hline 5 & 50 & 0.9132 & 0.00060 & 0.0659 \\
\hline
\end{tabular}

Table 4: Precision

\begin{tabular}{|c|c|c|c|c|c|c|c|}
\hline \multirow{2}{*}{\multicolumn{2}{|c|}{ PRECISION }} & \multicolumn{2}{|c|}{ REPEATABILITY } & \multicolumn{2}{|c|}{ REPRODUCIBILITY } & \multicolumn{2}{|c|}{ INTERMEDIATE PRECISION } \\
\hline & & MORNING & EVENING & DAY 1 & DAY 2 & ANALYST 1 & ANALYST 2 \\
\hline \multirow{6}{*}{$\begin{array}{l}\text { Absorbance } \\
20 \mu \mathrm{g} / \mathrm{ml}\end{array}$} & S1 & 0.6115 & 0.6118 & 0.6119 & 0.6110 & 0.6115 & 0.6110 \\
\hline & S2 & 0.6123 & 0.6125 & 0.6129 & 0.6120 & 0.6123 & 0.6120 \\
\hline & S3 & 0.6145 & 0.6146 & 0.6145 & 0.6135 & 0.6145 & 0.6156 \\
\hline & \begin{tabular}{|l|}
$S 4$ \\
\end{tabular} & 0.6134 & 0.6139 & 0.6140 & 0.6145 & 0.6134 & 0.6143 \\
\hline & S5 & 0.6121 & 0.6120 & 0.6123 & 0.6125 & 0.6121 & 0.6120 \\
\hline & S6 & 0.6130 & 0.6135 & 0.6134 & 0.6139 & 0.6130 & 0.6135 \\
\hline \multicolumn{2}{|c|}{ Mean } & 0.6128 & 0.61305 & 0.61317 & 0.6129 & 0.6128 & 0.61307 \\
\hline \multicolumn{2}{|c|}{ Standard Deviation (SI } & 0.00107 & 0.00112 & 0.001 & 0.0013 & 0.00107 & 0.00171 \\
\hline \multicolumn{2}{|c|}{$\begin{array}{l}\text { Relative Standard } \\
\text { Deviation(RSD) }\end{array}$} & 0.00175 & 0.00183 & 0.00162 & 0.00213 & 0.00175 & 0.00279 \\
\hline \multicolumn{2}{|c|}{ \%RSD } & 0.17454 & 0.18303 & 0.01623 & 0.21273 & 0.17454 & 0.27943 \\
\hline
\end{tabular}


Indo Global Journal of Pharmaceutical Sciences, 2020; 10(4): 27-31

Table 5: Accuracy

\begin{tabular}{|c|c|c|c|c|c|c|c|}
\hline \multirow{2}{*}{$\begin{array}{c}\text { RECOVERY } \\
\text { LEVEL }\end{array}$} & \multirow{2}{*}{$\begin{array}{c}\text { STANDARD } \\
\text { CONC. } \\
20(\mu \mathrm{g} / \mathrm{ml})\end{array}$} & \multirow{2}{*}{$\begin{array}{c}\text { TEST } \\
\text { CONC. } \\
20(\mu \mathrm{g} / \mathrm{ml})\end{array}$} & \multicolumn{3}{|c|}{ ABSORBANCE } & \multirow{2}{*}{ MEAN } & \multirow{2}{*}{ \%RECOVERY } \\
\hline & & & S1 & $\mathbf{S 2}$ & S3 & & \\
\hline $50 \%$ & $1 \mathrm{ml}$ & $0.5 \mathrm{ml}$ & 0.7613 & 0.7599 & 0.7625 & 0.7612 & $98 \%$ \\
\hline $100 \%$ & $1 \mathrm{ml}$ & $1 \mathrm{ml}$ & 0.8112 & 0.8154 & 0.8161 & 0.8142 & $99 \%$ \\
\hline $150 \%$ & $1 \mathrm{ml}$ & $1.5 \mathrm{ml}$ & 0.8612 & 0.8585 & 0.8621 & 0.8606 & $88 \%$ \\
\hline
\end{tabular}

Table 6: Robustness

\begin{tabular}{|c|c|c|c|}
\hline \multicolumn{2}{|c|}{ ROBUSTNESS } & $\begin{array}{c}\text { AT ROOM } \\
\text { TEMPERATURE } \\
\left(2^{\circ} \mathrm{C}\right):\end{array}$ & $\begin{array}{c}\text { ELEVATED } \\
\text { TEMPERATURE }\end{array}$ \\
\hline \multirow{6}{*}{ Absorbance at $20 \mu \mathrm{g} / \mathrm{ml}$} & S1 & 0.6123 & 0.6134 \\
\hline & S2 & 0.6133 & 0.6142 \\
\hline & $\mathbf{S 3}$ & 0.6148 & 0.6152 \\
\hline & S4 & 0.6139 & 0.6146 \\
\hline & S5 & 0.6129 & 0.6135 \\
\hline & S6 & 0.6143 & 0.6153 \\
\hline \multicolumn{2}{|l|}{ Mean } & 0.61358 & 0.61437 \\
\hline \multicolumn{2}{|c|}{ Standard Deviation (SD) } & 0.00093 & 0.00082 \\
\hline \multicolumn{2}{|c|}{ Relative Standard Deviation(RSD) } & 0.00151 & 0.00133 \\
\hline \multicolumn{2}{|c|}{ \% RSD } & 0.15093 & 0.1329 \\
\hline
\end{tabular}

Table 7: Ruggedness

\begin{tabular}{|c|c|c|c|}
\hline \multicolumn{2}{|c|}{ Ruggedness } & Analyst 1 & Analyst 2 \\
\hline \multirow{6}{*}{ Absorbance at $20 \mu \mathrm{g} / \mathrm{ml}$} & S1 & 0.6115 & 0.6110 \\
\hline & $\mathbf{S 2}$ & 0.6123 & 0.6120 \\
\hline & S3 & 0.6145 & 0.6156 \\
\hline & S4 & 0.6134 & 0.6143 \\
\hline & S5 & 0.6121 & 0.6120 \\
\hline & S6 & 0.6130 & 0.6135 \\
\hline \multicolumn{2}{|c|}{ Mean } & 0.6128 & 0.61307 \\
\hline \multicolumn{2}{|c|}{ Standard Deviation (SD) } & 0.00107 & 0.00171 \\
\hline \multicolumn{2}{|c|}{ Relative Standard Deviation(RSD) } & 0.00175 & 0.00279 \\
\hline \multicolumn{2}{|c|}{$\%$ RSD } & 0.17454 & 0.27943 \\
\hline
\end{tabular}

Table 8: LOD and LOQ

\begin{tabular}{|c|c|}
\hline Limit of Detection & Limit of Quantification \\
\hline $0.178 \mu \mathrm{g} / \mathrm{ml}$ & $0.542 \mu \mathrm{g} / \mathrm{ml}$ \\
\hline
\end{tabular}


Indo Global Journal of Pharmaceutical Sciences, 2020; 10(4): 27-31

Table 9: Summary of validation parameters for the proposed method

\begin{tabular}{|c|c|c|}
\hline S.NO & PARAMETERS & RESULTS \\
\hline 1. & $\begin{array}{c}\text { Absorption } \\
\text { maximum }\left(\lambda_{\max }\right)\end{array}$ & $219 \mathrm{~nm}$ \\
\hline 2. & $\begin{array}{l}\text { Beer's Law limit } \\
\qquad(\mu \mathrm{g} / \mathrm{mL})\end{array}$ & $10-50 \mu \mathrm{g} / \mathrm{mL}$ \\
\hline 3. & Slope & 0.009463 \\
\hline 4. & Intercept & 0.4169 \\
\hline 5. & $\begin{array}{c}\text { Coefficient of } \\
\text { correlation }\end{array}$ & 0.999 \\
\hline 6. & $\begin{array}{c}\text { Accuracy } \\
\text { (\%recovery) }\end{array}$ & $99 \%$ \\
\hline 7. & Precision (\% RSD) & $0.06123 \%$ \\
\hline 8. & $\begin{array}{c}\text { Robustness (\% } \\
\text { RSD) }\end{array}$ & $0.01329 \%$ \\
\hline 9. & $\begin{array}{l}\text { Ruggedness }(\% \\
\text { RSD) }\end{array}$ & $0.17454 \%$ \\
\hline 10. & $\begin{array}{l}\text { Limit Of Detection } \\
\text { (LOD) }\end{array}$ & $0.178 \mu \mathrm{g} / \mathrm{mL}$ \\
\hline 11. & $\begin{array}{c}\text { Limit Of } \\
\text { Quantification } \\
\text { (LOD) }\end{array}$ & $0.542 \mu \mathrm{g} / \mathrm{mL}$ \\
\hline
\end{tabular}

\section{CONCLUSION}

The proposed method development provides simple, specific, precise, accurate and reproducible results. The method was validated as per ICH guidelines in terms of specificity, linearity, accuracy, precision, limits of detection (LOD) and quantification (LOQ), robustness and ruggedness. The proposed method can be used for routine analysis of casein present in milk.

\section{ACKNOWLEDGEMENT}

The authors are also thankful to Srikrupa Institute of Pharmaceutical Sciences (Telangana, India) for providing the necessary facilities for research work.

\section{CONFLICTS OF INTEREST}

The authors declare no conflict of interest in this research article.

\section{FUNDING SOURCE}

No external funding declared.

\section{REFERENCES}

1. https://www.thespruceeats.com/casein-definition-1000967

2. http://ansci.illinois.edu/static/ansc438/Milkcompsynth/milkcom p_protein.html

3. Nakai, S., Le, A.C. Spectrophotometric determination of protein and fat in milk simultaneously. J. Dairy Sci., 1970; 53: 276-278.

4. Kamizake, N. K.; Gonçalves, M. M., Zaia, C. T, Zaia, D.A. Determination of total proteins in cow milk powder samples: a comparative study between the Kjeldahl method and spectrophotometric methods. J. Food Comp. Anal., 2003; 16 : 507-516.

5. Kuaye, A. Y. An ultraviolet spectrophotometric method to determine milk protein content in alkaline medium. Food Chem., 1994; 49: 207- 211.

6. https://www.ich.org/ fileadmin /Public WebSite / ICH-Products/ Guidelines/ Quality/ Q2-R1/ Step4 / Q2-R1-Guideline.pdf.

\section{DATA AVAILABILITY}

Not declared.

Indo Global Journal of Pharmaceutical Sciences( ISSN 2249 1023; CODEN- IGJPAI; NLM ID: 101610675) indexed and abstracted in CrossRef (DOI Enabling), CNKI, UGC CARE Journal List, EMBASE (Elsevier), National Library of Medicine (NLM) Catalog (NCBI), ResearchGate, Publons (Clarivate Analytics), CAS (ACS), Index Copernicus, Google Scholar and many more. For further details, visit http://iglobaljournal.com 